\title{
Impact of Globalization on Budget Deficit, Inflation and Eco- nomic Growth: The Case of Pakistan
}

\author{
Saira Mumtaz ${ }^{1}$, Muhammad Zeeshan Younas*2 \\ ${ }^{1}$ COMSATS University, Islamabad \\ ${ }^{4}$ Quaid-I-Azam University, Islamabad
}

\begin{abstract}
Globalization is a multi-dimensional phenomena with profound impact on different aspects of the modern world including economic, social, political, cultural, environmental, and geographical. This study is an attempt to analyze the subject that how various components of globalization i.e. trade openness, financial liberalization and labor mobility impact the economic dynamics of a developing country by affecting the performance of selected macroeconomic variables including budget deficit, inflation and economic growth. In this particular research we used the terms trade openness and liberalization along with financial openness, financial liberalization and financial development interchangeably. The purpose is to capture the overall impact irrespective of the nature as considering nature would lead to contradictory results. The increasing importance of labor flow is also given due attention in this study as human capital is an inevitable avenue for the effective and sustainable growth of any country. Various global factors effect budget deficits, inflation and economic growth with varying intensities depending upon the size and dynamics of the economy. The empirical analysis involves the time series data for years 1973-2014 for the case of Pakistan. The Autoregressive distributed lag (ARDL) methodology is used to derive the results and conclusion further seconded by the policy suggestions made in the light of this study.
\end{abstract}

\section{Introduction}

Globalization is a multidimensional phenomenon that has now become a necessity of time. It has cultural, political, economic, environmental and many other aspects. The quick and rapid exchange of products, knowledge and information are the most blissful aspects of globalization, transforming the world in to a global village (Afzal, 2006). Most obvious and vital features of globalization grew in last decades of 19th century with the swift integration of the world economies and cultures. In 2000, International Monetary Fund (IMF), indicated the distinguished economic aspect of globalization as trade and transaction, capital and investment movements, labor flows together with environmental challenges such as global warming, water and air pollution, over fishing etc. Globalization is not new but its changing magnitude has profound implications that vary with economies depending upon their dynamics, structure and

*Corresponding author.

Email: mrzee38@yahoo.com 
extent of openness (Taylor, 2006). More open economies have greater ability to capture new ideas (Obstfeld, 2004).

Economic part of the globalization has now become a process which enables the gradual integration of national economies. It has greatly facilitated the dismantling of barriers and diminishing of boundaries in order to make economic activities more convenient than ever. It has considerably raised the propensity to import and propensity to invest abroad, making a commendable contribution towards raising global trade volumes and investments globally. The exchange of fungible, exchangeable and/or switchable jobs, (Friedman, 2005), is the start of a new era towards global economic integration via outsourcing, in sourcing, home sourcing offshoring etc. The financial sector has also turned out to be more independent and more impactful due to various recent developments for which the credit to globalization is a must.

The study aims to investigate how various components of globalization (i.e. financial liberalization, trade openness and labor mobility) are impacting macroeconomic performances of various variables namely budget deficit, inflation and economic growth of a developing country. How various aspects of globalization are contributing to budget deficit of a country? What role globalization is playing in inflation dynamics for developing economies? How impact of globalization is incorporated in overall economic growth of developing countries like Pakistan? The current study shall try to find the answers of these research questions. The study could prove to be a great help for policy makers enhancing their understanding about the ways through which various components of globalization affect the dynamics of economy by means of macroeconomic indicators namely budget deficit, inflation and economic growth. It further provides a meaningful insight to students about the need to understand globalization and its implications for economies.

\section{Literature Review}

\subsection{Globalization and Government Budget Deficits}

Normally all governments are thought to live within their means, as going beyond means is onerous for the economy. The government budget deficit is thought as abnormal and undesirable that further paves way for various serious economic ills. Globalization has laid significant impact on the government budget deficits through trade openness, financial/capital liberalization and labor mobility. Trade openness and liberalization directly affects budget balances via terms of trade. The indirect channels like corruption, income inequalities, prejudices, etc. can also have profound implications for the budget balances. According to Dutch Disease Hypothesis various external economic shocks make governments behave in a certain way that contributes to budgetary imbalances (Collier and Gunning, 1999). However, the Political Pressure Argument suggests that cost which pertains to errors of foresight in case of global disturbances in trade patterns could worsen budget deficit problems (Alesina and Perotti, 1995).

It is important here to remember that there are some key distinctions that vary with natural openness and policy induced openness. The two might lead to conflicting results as far as their influence on budget balances is analyzed. The natural openness relies on structural determinants like country size and geographical characteristics. The policy induces openness is largely dependent upon decision makers (Combes and Saadi-Sedik, 2006). Current study has analyzed the effect of trade imbalances on improving/deteriorating the budget deficit irrespective of the nature of openness. The terms of trade instability is facilitated primarily by various 
global economic factors. It is a fundamental determinant of outlook of any economy by gauging its macroeconomic performance.

Beggar your neighbor strategy is another way in which remedy by a country to cure economic ill tends to worsen the economic problem of the trading partner. It can work via trade impediments as restricting imports through quota or tariffs. Currency devaluation is another way that makes import more expensive and exports cheaper. In this way a country strategy can have profound impact on not mere domestic trade patterns but also on terms of trade of other trading partners. Economic internationalization, particularly, financial- side is known to exert downward pressure on budget deficit. Market participants are discouraged by the situation thinking large sustained budget deficit as a question to government's performance and proceeding inflation risks.

Financial internationalization offers greater access to opportunities of borrowing but also makes economies vulnerable towards greater market punishments. Singh (2000) defined capital account liberalization as the method through which nations tend to promote capital account liberalization. It is done by possible elimination of quantitative restrictions, like controls, taxes, subsidies that impede capital transactions, making them more favorable and convenient. It also essentially involved easing of various barriers on international financial transactions. Besides, it also facilitated the sale and purchase of real or financial assets across boundaries. Capital account is interchangeably used with capital and financial account throughout this study. The capital flows are advocated by both neo-classical and Keynesians differently; neo-classical advocated full capital account liberalization through Adam Smith's invisible hand assuming the automatic functioning of the price mechanism, while Keynesian on the contrary, proposed for government intervention keeping in view the very fact that the weak economic and institutional fundamentals cannot deal with short term capital flows effectively. This situation is more possible due to their speculative nature in developing countries which tended to deteriorate budget deficits of governments.

Globalization has an admirable role to contribute towards human capital development, promoting the skilled labor participation than the unskilled labor. Many services are now tradable, enhancing the opportunities of employment across the countries. IMF (2006) indicated that economic globalization over time depends greatly on human innovation and technological progress. Human capital proved to be another significant and vital avenue contributing for strong economies. Various analysis provide evidence that taxes paid by immigrants would not only offset any new spending, but also play an active role to reduce the deficits of the recipient and host economies. These immigrants also facilitate the economic activity within an economy by boosting demands and consumption aspects along with sharing the tax burden of the native citizens. It also has paved way for job creation, promoting innovation and utilizing the most talented workforce around the world. The skill of labor is very important tool to enable the transfer of technology from one part of the world to another.

Kim and Singal (2000) examined how insecurity from the international capital market led a government to tighten its budget deficit in case of free capital mobility and vice versa. Even the most conservative measure showed that government budget deficits reduced considerably if capital account liberalization were exogenously imposed. The countries with fixed exchange rate regime provided strong evidence of this disciplinary effect. It also proved valid for countries with weak central bank independence. On the contrary, the countries with flexible exchange rate regime negated the fact. Stiglitz (2000) examined financial aspects of globalization and maintained that the influx of hot money into and out of the country that so frequently followed after capital market liberalization aroused various insecurities. He further mentioned small devel- 
oping countries were too feeble to keep pace with financial liberalization. Rapid capital market liberalization could not harness desired gain in these countries on account of their structural, functional and institutional weaknesses.

Combes and Saadi-Sedik (2006) revealed that the empirical influence of trade openness on budget balances is relatively strong despite ambiguous net effect. Trade openness made many economies more vulnerable to external shocks irrespective of the nature. Governments, including in developing countries, often fear the fact that their budget condition is already problematic and dropping tariffs lead to bigger budget shortfalls. For that reason, they resist liberalizing their trade regimes. Likewise, Aghion et al. (2007) analyzed the case of OECD countries for recurring dynamics of budget policies. They maintained that the financial development and openness level has positive relation with the cyclical budget policy. The recurring budget deficit has positive influence on budget policy in case of low financial development.

Ratha et al. (2005) investigated the twin-deficits theory for the case study of Indian economy and found that the budget deficit increases the expansion of imports within the economy. This situation tends to worsen the trade deficit as proposed by Keynesian. It also causes the domestic currency to appreciate due to surge in the domestic interest rates, which further contributed to trade deficits. Similarly, BAYRAK and Ömer (2012) analyzed the Twin deficits and the development process associated with it. They examined both the Keynesian Approach and Ricardian Equivalence Approach for the study. The empirical findings of the study revealed that there is a significant correlation between both short run and long run budget deficits and current account deficits.

A seminal contribution is made by Meyer and Shera (2015), describing that the remittances are one of the key paybacks of international migration. Workers' remittances provide a reliable channel and an important financial flow that greatly contributes towards progress of many developing countries. The free movement of labour helps the developing economies to gain important foreign currency revenue. In particular, migrants' transfer of funds, provided a suitable source of inflows of foreign currencies that can also be used to repay foreign debts and/or financing the budget deficits.

In order to shed an optimistic light on the complex linkages between globalization and budget deficit, Malit Jr and Naufal (2016) studied that for decline in world oil and gas prices, the workers remittances became a possibly feasible solution to address government budget deficits in the Gulf Cooperation Council (GCC) countries. The study also examined the reactions of several GCC regimes for long-term possible inferences on nationwide labor marketplaces and immigrants along with their families both in the destination and origin countries.

\subsection{Globalization and Inflation}

Inflation is an economic ill that can make economic activities harder for every sector of the economy. The poor who get no hedge against it are most vulnerable to horrible implications of inflation. Therefore it further distorts the resource allocation process due to increasing uncertainty involved in price mechanism. Monetary expansion, unexpected shocks in real and financial sector, increase in import prices and global inflationary patterns are main contributors of inflation. Inflation created uncertainty in economy retards economic growth. Friedman (2005) popular adage supports the fact "inflation is always and everywhere a monetary phenomenon" which is now finding new connotations. Globalization has shown wonders to promote deflation by providing better access to cheap labor force from labor abundant countries through sales of low cost goods. In Pakistan, it is often argued that there are many factors that contribute to- 
wards the high rate of inflation. The few striking and notable reasons for increasing inflation are seinorage, fiscal imbalances, deficit financing via external internal borrowing, economic growth and exchange rate depreciation (Agha et al., 2006). Beggar thy neighbor strategy suggests that large economies can have considerable effect on inflation dynamics of many other economies. Inflation cycles are vulnerable to various global shocks through commodity, trade and financial channels.

Openness tends to reduce inflationary pressures usually through access to cheap imports and raw materials along with promoting domestic market competitions within an economy (Afzal, 2006). The positive impact of trade openness on inflation could result as an outcome of measures by policy makers, to capture the gains from international markets due to money growth. Thus they strive for monopolistic power in the international markets in this way. Also, financial openness in some studies provided negative relationship with the average inflation.

Ju and Wei (2010) analyzed that the financial openness shows negative linkages with the average inflation rates. They also revealed that there is no significant measurable effect of financial openness found on Government budget deficit. Sentance (2007) revealed that the response of domestic inflation to domestic capacity pressures is quite dampened by the increase in trade and specialization thereby, making it more sensitive to global shocks. The increasing competition dealing with diversified products from abroad can restrict the price setting capacity of companies to raise prices due to increasing domestic demand. Similarly the increased recognition of off shoring for production and access to cheaper worker from abroad also plays a significant role in domestic price regulation mechanism.

Borio and Filardo (2007) argued that the existing models of inflation are too "country-centric". It is observed that they are not taking into account the role of global factors that significantly influence the inflation. The increasing need of a more "globe-centric" approach depicting the swift integration of the world economies commonly referred to as "globalisation". They also studied various indicators of foreign influences on indigenous inflation e.g altering imports and change in oil prices. Furthermore, over the course of time, the influence of such global factors has been expanding, thereby becoming more dominant and significant, especially in the recent era.

Likewise, Guerrieri et al. (2010) estimated an open economy responses to change in competitive pressure from abroad and found that there is significant role of foreign competition on domestic inflation. By making a comparison between the unrestricted and restricted specifications, evidence supported the fact that foreign competition has significant influence on the behaviour of inflation in the traded goods sector. The results suggest that the domestic goods inflation is lowered by foreign competition by about 1 percentage point during 2000-2006. The results also provide supporting evidence against demand curves with a constant elasticity in the case of monopolistic competition.

Correspondingly, Badinger (2009) postulated that the globalization has a significant contribution towards reducing the worldwide inflation rate. One way to make reduction in inflation is possible by urging the policy makers to formulate strategies which are useful in achieving the stable inflation. He further analyzed the impact of variables for example real GDP growth, trade openness, short-term interest rate, actual Inflation and financial openness for various countries in his analysis. The study determined that the negative association between financial openness and trade openness in context of the inflationary pressures has for many countries. The result could not be found effective for the OECD markets.

As far as developing economies are concerend, Zakaria (2010) investigated the association between trade openness and inflation in case of Pakistan via employing Generalised Method of Moments (GMM) technique. The positive results pertained to the fact that openness and 
inflation are greatly influenced by both country and time specific effect. Inflation is chiefly influenced by control variables such as fiscal deficit, exchange rate depreciation, money supply, terms of trade, foreign inflation, foreign debt and democracy. Other factors that contributed towards a country's inflation rate include better development and a shift from pegged to floating exchange rate regime..

Lotfalipour et al. (2013) studied the framework of trade openness and inflation rate. They provided evidence from different countries, comprising both negative and positive effects which openness exert on inflation rate. In contrast to Romer (1993), who demonstrated that a negative correlation existed between them, his study revealed the very fact that those countries are more exposed to higher rate of inflation which are engaged in international trade to a greater extent which further triggered the restrictions to achieve economic growth. He also came up with the conclusion that monetary authorities' policies, on account of possessing monopolistic power in the international market, can also positively impact inflation via trade openness so that benefits of monetary growth can be reaped.

\subsection{Globalization and Economic Growth}

Economic Growth is one of the most significant macroeconomic indicators to provide an insight in to the economic performance of a country. It clearly depicts the standing of a country in terms of economic performance in the world. Globalization is expected to enhance economic growth of a country by efficient and effective resource allocation, their utilization and harnessing maximum gains associated with growth. Globalization has the tendency to stabilize output by allowing producers to serve a more variegated global market rather than catering to a local market only. It is also observed that improvement and innovation in financial development levels over recent times have played a commendable role in decreasing transaction cost and increasing remittances for various economies stimulating growth in these countries. Kose et al. (2006) maintained that the openness as a result of distinction between de jure and de facto is a matter of great importance. The capital inflows of a country are considerably determined by the extent of capital control measures and sound disciplining. In this particular study, we overlook the nature specific outcome of defacto/dejure measure for empirical analysis. The purpose is to capture the impact of capital flows on the whole irrespective of the nature.

Another strand of literature links globalization to economic growth via global financial crisis. A prominent study in this regard is conducted by Asghar and Hussain (2014) revealed that the growth rate declines due to the sub-prime mortgage financial crisis 2007-08. They maintained that a considerable decline in economic growth was observed in most national economies around the world after the financial crisis of 2007-08. Financial sector across the globe is playing an important role to stabilize itself that further contributes to more output stability. However, it also makes financial institutions more vulnerable towards risks, transmitting financial shocks more swiftly across borders (Mishkin, 2006). Globalization is encouraging competition, innovation, diversification, structural and institutional reforms that enable markets to switch to better performances, thus promoting growth. Previous literature postulates that openness plays a crucial role in the efficient and effective resource allocation along with utilization of resources through comparative advantage which further leads to better Economic Growth (IMF, 2006).

Giuliano and Ruiz-Arranz (2009) maintained a vague relationship corresponding to economic growth exhibited by overseas remittances and financial innovations. By using crosscountry data series for developing countries, they revealed the interaction between remittances and financial development and its impact on growth. The empirical analysis supports the fact 
that remittances play a commendable role to promote growth in countries with less financial development levels. Besides, Shaikh and Shah (2008) concluded globalization as the rapidly growing integration of economies and societies around the world. Makhlouf and Mughal (2011) claimed that signs of the Dutch diseases exhibited by Pakistan's economy as a consequence of remittance inflows. Javid et al. (2012) examined not only the imperative role that remittances play but also its implications on economic growth and poverty alleviation in Pakistan using ARDL.

\section{Research Methodology}

\subsection{Theoretical Framework}

The impact of globalization on our selected macroeconomic variables i.e. budget deficit, inflation and economic growth is given in figure 3.1. It highlights various components of economic globalization that have profound impact on the performance of selected macroeconomic variables. The global economic disturbances like exchange rate fluctuations, demand/supply shocks etc. are now making inflation more sensitive to external disturbances like financial market crisis, oil price shocks etc. Various global economic shocks have considerably influenced the dynamics of inflationary process by impacting the incentives of central banks to anchor inflation (Mishkin, 2006). Large Budget deficit can have significant impact on inflation through money supply or formation of price expectation.

The flow of new technology from advanced countries requires skilled labor. The labor mobility and portion of skilled labor in the economy is a vital part of a growing economy. The improving levels of incomes as result of outsourcing, insourcing, home sourcing, offshoring etc. is also significantly contributing towards better economic performance. It is also found that increasing remittances inflow may have temporary shock on incomes and may contribute a significant role to amplify the growth process in the long-run (Arezki and Brückner, 2012). Also, shocks to remittances and lacking financial development levels are found to inversely impact the economic situation.

Globalization through increasing economic internationalization is offering more diversification, structural and institutional reforms, competition and challenges are offering economies wider opportunities to thrive. But at the same time it makes economies more vulnerable to global economic disturbances and crisis. It has now become an inevitable phenomenon, as a country cannot thrive in isolation anymore in this global age and more efforts are duly to be made on part of every country to benefit from globalization. Following the footsteps of Afzal (2006); Zakaria (2010), we developed the following empirical models for budget deficit, inflation and economic growth, we developed:

\section{Model 1}

$$
\ln B D_{t}=\alpha_{1}+\alpha_{2} \ln \mathrm{TOT}_{t}+\alpha_{3} \ln F D I_{t}+\alpha_{4} \ln R E M_{t}+\alpha_{5} \ln R G D P_{t}+\varepsilon_{1 t}
$$

This is uniformly recognized that the trade openness tends to improve budget deficits by improving the current account deficits. The financial internationalization is also thought to improve deficits as it paves way for transfer of technology, generates employment and tax revenues, facilitates investments, improves and initiates human capital development in case of 


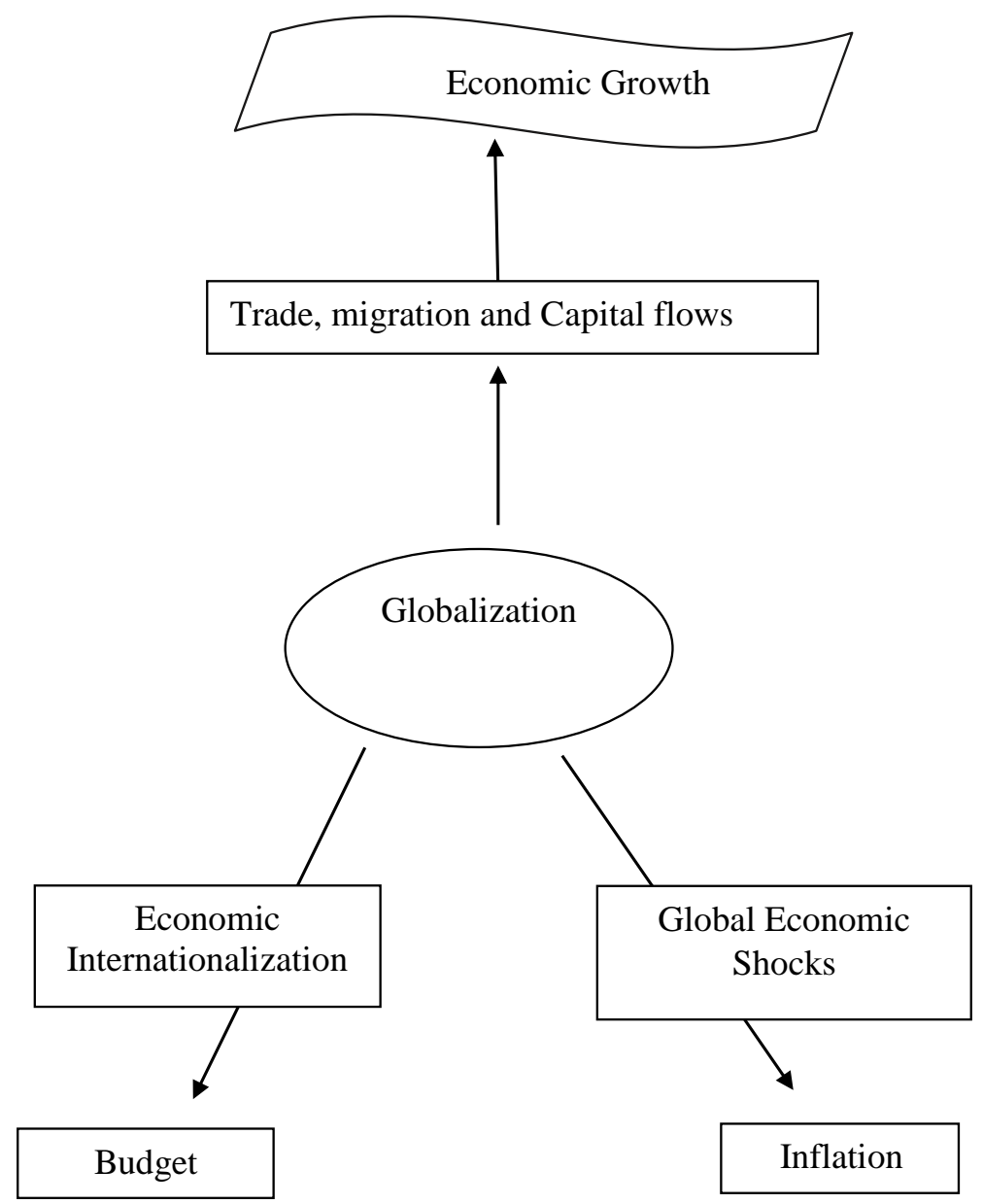

Figure 1: Economic globalization impacts on Budget Deficit, Inflation and Economic Growth

sound disciplining. Likewise, remittances are anticipated to improve budget deficit for sound framework as it facilitates the consumption and investment within an economy thereby improving the current account balances. The migrant funds transfer in foreign currency could also be used to repay the foreign debt. The budget deficit shows that government expenses exceed government revenues and investors perceive it as governments failing performance along with inflationary risks that result in negative relationship between budget deficit and real economic growth.

\section{Model 2}

$$
\ln I N F_{t}=\beta_{1}+\beta_{2} \ln \mathrm{TOT}_{t}+\beta_{3} \ln F D I_{t}+\beta_{4} \ln R E M_{t}+\beta_{5} \ln R G D P_{t}+\varepsilon_{2 t}
$$


Inflation causes uncertainty in the economy and also affects the costs of business in the economy, troubling every sector of economy. It also discourages foreign investors who lose confidence to invest in highly inflated economies. Trade openness is found to have inverse relation with the inflationary pressures by enhancing competitions and providing cheap alternatives from the other parts of the globe, which tends to control price hikes. It is also known to increase output productivity in the economy, which results in reducing inflationary pressures. The outcomes of trade openness are more time specific and country specific (Zakaria, 2010) depending upon dynamics of an economy. Financial internationalization is also found to have varying relationship with inflation depending upon the nature of an economy like level of financial development, policies, institutions etc. Guerrieri et al. (2010) found FDI to reduce inflationary pressures in traded good sector by offering more diversity and competition. Remittances tend to reduce inflationary pressures if they are utilized in a productive way. On the contrary, remittances can also contribute to surge demand pull inflation if they are not channelized to productive avenues.

\section{Model 3}

$$
\ln R G D P_{t}=\varphi_{1}+\varphi_{2} \ln R E M_{t}+\varphi_{3} \operatorname{lnFDI_{t}}+\varphi_{4} \operatorname{lnTOT_{t}}+D U M+\varepsilon_{3 t}
$$

The real GDP is an in inflation-corrected GDP that reflects the true picture of performance of each sector of an economy within a certain time period. Remittances are found to positively contribute to an economy growth by facilitating consumption, investment related activities in the economy along with increasing financial development in the economy. They improve the current account balances and thereby accelerate growth. In case they are not put to productive utilization, like their increased utilization in non-tradable goods sector (real estate housing), it triggers inflationary pressures, making exports less competitive and import more attractive which stampedes growth. Trade openness is anticipated to enhance growth by stimulating productivity, initiating competitions and easy access to cheap raw material and alternatives. The financial internationalization is also known to accelerate growth by transfer of new technologies, increased production and investment, generating employment opportunities and tax revenue.

\subsection{Economic Methodology}

It is important that we must check the stationary of data series under study before proceeding for empirical analysis. In case of empirical analysis of non stationary data results turn out to be spurious which is not desirable. In this context there is variety of tests available to check the stationarity of data and if found non stationary change them to stationary. These tests include Augmented Dickey Fuller test (ADF), Dickey Fuller test, Phillip -Perron test, KPSS test, ADF_GLS test etc. depending upon the need of data. The commonly use and valid for large data set test namely ADF test is used in this study to check the stationarity of our data series. If all variables are integrated of order one I(1) Johansen Multivariate Co-integration Methodology will be used. However, if variables are a mix I(0) and I(1), then Autoregressive Distributed Lag (ARDL) methodology will be applied.

\subsection{Autoregressive Distributive Lag (ARDL) Approach To Cointegration}

The empirical economic analysis in many studies makes use of various cointegration techniques. These techniques provide variety of choices like Johansen ,Johansen-Juselius and Pe- 
saran and Pesaran ARDL approach that are utilized depending upon the requirement of the empirical analysis. These empirical analyses are used to determine the relationships between the dependent and independent variables. The ARDL model has some considerable and striking advantages over traditional cointegration approaches which make it more robust approach for cointegration. Firstly, as compared to other techniques this technique has appeared to be more robust in small or finite samples that comprise of 30 to 80 observations, giving it an edge. Secondly, whether regressors are of I(0) or I(1) or mutually integrated it can be utilized irrespectively, providing an additional advantage of using this technique. However, the ARDL procedure will turn out to be inefficient in the existence of I(2) or higher order series which needs to be sorted clearly. Thirdly, the ARDL Model provides the most parsimonious way of modeling which efficiently applies on general-to-specific framework, taking sufficient number of lags to capture the data generating process. It leads to the most parsimonious method that tends to qualify all the diagnostics, keeping the reduced form of model with significant variables and reducing the insignificant explanatory variables from the model. The ARDL in terms of unrestricted error correction model (UECM) can be represented as given in equation 3.4, equation 3.5 and equation 3.6 which are used to determine long run and short run relationships between variables.

$$
\begin{gathered}
\Delta \ln B D_{t}=\alpha_{0}+\sum \gamma_{i} \Delta \ln B D_{t-i}+\sum \gamma_{2 i} \Delta \ln T O T_{t-i}+\sum \mathrm{Y}_{3 i} \Delta \ln F D I_{t-i}+\sum \gamma_{4 i} \Delta R E M_{t-i} \\
+\sum \gamma_{5 i} \Delta \ln R G D P_{t-i}+\theta_{1} \ln B D_{t-1}+\theta_{2} \ln T O T_{t-1}+\theta_{3} \ln F D I_{t-1}+\theta_{4} \ln R E M_{t-1} \\
+\theta_{5} \ln R G D P_{t-1}+\varepsilon_{1 t}
\end{gathered}
$$

The models provide the choice of different criteria like SBC, AIC, RBC and HQC. The model are selected on the basis of these criteria provided. The ARDL method can appropriately distinguish between dependent and explanatory variables and effectively tackles the issues arising from autocorrelation and endogeneity. Which provides it an edge over traditional cointegration method that often encounters the problem of endogeneity. ARDL cointegration estimates successfully compute both short run and long run relationships simultaneously, providing unbiased and efficient estimates for the selected models. It also works appropriately for single equations. The ARDL model takes into account the appropriate lags length as per requirement of the model and directs the data generating process in a general to specific modeling framework. In case there exists cointegration among variables in our models long run equations for model 1 , model 2 and model 3 are given as: 


$$
\begin{aligned}
\ln B D_{t}= & a_{1}+\theta_{1} \ln \left(B D_{i}\right)_{t}+\theta_{2} \ln (T O T)_{t}+\theta_{3} \ln (F D I)_{t} \\
& +\theta_{4} \ln (R E M)_{t}+\theta_{5} \ln (R G D P)_{t}+£ B D_{t} \\
I N F_{t} & =a_{1}+\theta_{1}\left(I N F_{i}\right)_{t}+\theta_{2} \ln (F D I)_{t}+\theta_{3} \ln (T O T)_{t} \\
& +\theta_{4} \ln (R E M)_{t}+\theta_{5} \ln (R G D P)_{t}+£_{I N F t} \\
\ln R G D P_{t} & =a_{1}+\theta_{1} \ln \left(R G D P_{i}\right)_{t}+\theta_{2} \ln (F D I)_{t}+\theta_{3} \ln (T O T)_{t} \\
& +\theta_{4} \ln (R E M)_{t}+\theta_{4} \ln (D U M)_{t+} £_{G D P t}
\end{aligned}
$$

where $\theta$ shows the long run relationships among the variables of models.

Once the lag order of the model is identified, ARDL model also allows the cointegration relationship to be estimated by OLS. ARDL approach also leads to construction of Error Correction Model (ECM). The ECM establishes short run dynamics adjustment with long run equilibrium without losing long run information. In other words it shows the speed of adjustment towards long run equilibrium. The above advantages of the ARDL technique clearly advocate the application of ARDL approach in the this study to analyze the relationship among the dependent and independent variables in three selected models. The hypothesis analysis leads to test the null hypothesis of no cointegration against the alternative hypothesis that there exists cointegration between all variables. For this purpose F-statistic has been used. This test is sensitive to the number of lags. The Error Correction Model (ECM) is constructed to examine and establish Short run and long run linkages. The restricted ECM description of the ARDL model is used to determine the short run dynamics, also given as under:

$$
\begin{aligned}
& \Delta B D_{t}=\alpha_{0}+\sum \alpha_{i} \Delta B D_{t-i}+\sum \beta_{i} \Delta T O T_{t-i}+\sum \beta_{i} \Delta F D I_{t-i}+\sum \beta_{i} \Delta R E M_{t-i} \\
& +\sum \beta_{i} \Delta R G D P_{t-i}+\mu E C M_{t-i}+v_{t} \\
& \Delta I N F_{t}=\alpha_{0}+\sum \alpha_{i} \Delta I N F_{t-i}+\sum \beta_{i} \Delta T O T_{t-i}+\sum \beta_{i} \Delta F D I_{t-i}+\sum \beta_{i} \Delta R E M_{t-i} \\
& +\mu E C M_{t-i}+v_{t} \\
& \Delta R G D P_{t}=\alpha_{0}+\sum \alpha_{i} \Delta R G D P_{t-i}+\sum \beta_{i} \Delta T O T_{t-i}+\sum \beta_{i} \Delta F D I_{t-i}+\sum \beta_{i} \Delta R E M_{t-i} \\
& +\mu E C M_{t-i}+v_{t}
\end{aligned}
$$

The null hypothesis depicting no cointegration for the variables of budget deficit, inflation and economic growth against alternative research are given as:

\section{Model 1} exists)

$H_{0}: \theta_{1}=\theta_{2}=\theta_{3}=\theta_{4}=0$ Globalization has no significant impact on Budget Deficit (No cointegration

$H_{1}: \theta_{1}=\theta_{2}=\theta_{3}=\theta_{4} \neq 0$ Globalization has significant impact on Budget Deficit (Cointegration exists) 


\section{Model 2}

$H_{0}: \lambda_{1}=\lambda_{2}=\lambda_{3}=0$ Globalization has no significant impact on inflation (No cointegration exists)

$H_{1}: \lambda_{1}=\lambda_{2}=\lambda_{3} \neq 0$ Globalization has significant impact on inflation (Cointegration exists)

\section{Model 3} exists)

$H_{0}: \mathrm{Y}_{1}=\mathrm{Y}_{2}=\mathrm{Y}_{3}=0$ Globalization has no significant impact on Economic growth (No cointegration exists)

$H_{c 1}: Y_{1}=Y_{2}=Y_{3} \neq 0$ Globalization has significant impact on Economic growth (Cointegration

\section{Empirical Analysis}

\subsection{Data Sources}

The annual time series data, which was used in this study, were taken from 1972 to 2014. The data were obtained from international financial statistics CD-ROM (2014), Economic survey of Pakistan, Handbook of Statistics on Pakistan Economy 2010 and Annual reports of State Bank of Pakistan.

\subsection{Unit Root Test}

Table 4.1: ADF test Statistics

\begin{tabular}{lccc}
\hline Variables & \multicolumn{2}{c}{ ADF Test Statistics } & \multicolumn{2}{c}{ Order Of Integration } \\
\hline \multicolumn{3}{c}{ ADF -LEVEL } & ADF- $1^{\text {st }}$ DIFF \\
LFDI & -3.98 & $-3.98^{*}$ & I (1) \\
1REM & -1.34 & $-5.62^{*}$ & I (1) \\
LTOT & -1.35 & $-6.77^{*}$ & I (1) \\
LBD & -5.83 & $-17.79^{*}$ & I (1) \\
INF & $-4.78^{* *}$ & -11.76 & I $(0)$ \\
LRGDP & $-3.61^{* *}$ & -4.18 & I $(0)$ \\
\hline
\end{tabular}

*indicates stationarity at $1 \%,{ }^{* *}$ indicates stationarity at $5 \%$

\subsection{Bounds Test}

Since mixed stationarity results were obtained via ADF test, therefore, ARDL (Autoregressive distributed lag) method of cointegration is applied keeping in view the sample size and their respective stationarity levels. Further ARDL method was used to test for cointegration and check the F-stat results whether they fall between upper bound and lower bound or exceed the upper bound value. In case f-stat exceeds upper bound value, it was found that cointegration exists between dependent and independent variable of that respective model. 
Table 4.2: ARDL selected based on Schwartz (SC) Information Criterion

\begin{tabular}{lcc}
\hline MODEL (Equation) & F-STAT & DECISION \\
\hline 1.LBD=f(LTOT,LREM,LFDI,LRGD) & 5.08 & Cointegration \\
2.INF=f(LFDI,LREM,LTOT,LRGDP) & 6.11 & Cointegration \\
3.LRGDP=f(LFDI,LTOT,LREM,DUM) & 3.99 & Cointegration \\
\hline
\end{tabular}

Model 1, table 4-2 show a long run relationship between dependent variable and independent variables. The F stat value is 5.08 which falls above upper bound of the critical value. This means that null hypothesis was rejected, i.e. relationship between dependent and independent variables in the long run relationship. Model 2 results F stat value is 6.11 which falls above upper bound of the critical value which lead to rejection of null hypothesis which is that no relationship exists between dependent and independent variables in the long run. Similarly, model $3 \mathrm{~F}$ stat value is 3.99 which falls above upper bound of the critical value.

\subsection{Long Run Estimates}

Table 4.3: Model 1

\begin{tabular}{lcccc}
\hline Variable & Coefficient & Std. Error & T-Statistic & Prob. \\
\hline LTOT & -0.629589 & 0.267407 & -2.354428 & 0.0267 \\
LREM & 0.406016 & 0.130285 & 3.116356 & 0.0046 \\
LFDI & 0.043243 & 0.107821 & 0.401064 & 0.6918 \\
LRGDP & -0.806834 & 0.225650 & -3.575594 & 0.0015 \\
C & 2.747794 & 7.470075 & 3.848394 & 0.0007 \\
\hline
\end{tabular}

The results presented in table 4-3 for long run coefficients show that term of trade (TOT) is negatively and significantly related to budget deficit in the long run. The one percent increase in TOT decreases fiscal deficit by 0.6 percent. Combes and Saadi-Sedik (2006) also discussed the term of trade role in improving the budget deficit situation in developing countries. The increasing trade openness causes structural and institutional reforms which tend to improve trade policies and trade volumes that ultimately have positive role in decreasing budget deficit. Remittances coefficient in table 4-3 shows positive and significant relationship with budget deficit in long run. One percent increase in remittances raises deficit by 0.4 percent. This could be the result of remittances utilization for non-productive sectors of the economy along with nontradable goods like real estate and property related investments by expats. The negative effect can be produced when remittances generate demand greater than the economy's capacity to produce. It can make an economy rely heavily on imports. The results also provide evidence that these remittances have induced consumption expenditures rather than private savings. This may further lead to balance of payments pressure, a slower growth of employment opportuni- 
ties, and consequently to a further increase in the incentive to emigrate. These views are also supported by Meyer and Shera (2015).

Foreign direct investment table 4-3 is found to be positively and insignificantly linked to budget deficit in the long run for Pakistan. One percent increase in FDI is found to change deficit by 0.04 percent but has no significant impact in the long run. Agrawal and Khan (2011) maintained in his study that FDI in Pakistan is more directed to services and telecom sector and less directed to tradable sector,reducing the export oriented FDI, which has negligible impact on budget deficit. Ju and Wei (2010) found no significant measurable relationship between financial openness and budget deficit as it also greatly depends on institutions, policies, sound disciplining and better management etc. Additionally, the real GDP in table 4-3 is found to be negatively and significantly related to budget deficit for Pakistan in the long run. One percent increase in real GDP tends to reduce budget deficit significantly by 0.8 percent in the long run. The prolonged deficits show shortage of revenues and savings by national government and exceeding expenses which tend to reduce the real economic growth in the long run concluding an inverse relationship between the two.

Table 4.4: Model 2

\begin{tabular}{lcccc}
\hline Variable & Coefficient & Std. Error & t-Statistic & Prob. \\
\hline LTOT & 0.307236 & 0.152577 & 2.013643 & 0.0534 \\
LFDI & 0.095918 & 0.038622 & 2.483502 & 0.0190 \\
LREM & 0.055892 & 0.027017 & 2.068754 & 0.0476 \\
LRGDP & -0.177473 & 0.092123 & -1.926479 & 0.0639 \\
C & 0.931608 & 1.071740 & 0.869248 & 0.3918 \\
\hline
\end{tabular}

Table 4.5: Model 3

\begin{tabular}{lcccc}
\hline Variable & Coefficient & Std. Error & t-Statistic & Prob. \\
\hline LTOT & 0.875187 & 0.504404 & 1.735091 & 0.0975 \\
LFDI & 0.579231 & 0.244420 & 2.369816 & 0.0275 \\
LREM & 0.238319 & 0.079500 & 2.997714 & 0.0069 \\
LRGDP & 0.291975 & 0.200587 & 1.455599 & 0.1603 \\
C & 1.191342 & 2.249674 & 0.529562 & 0.6020 \\
\hline
\end{tabular}

\subsection{Short Run Analysis}

After long run analysis we are in need to develop Error Correction Models (ECM) for model 1, model 2 and model 3. An ECM essentially consists of two important aspects. The first aspect 
deals with the estimation of short run coefficients. The second aspect deals with error correction term (ECT) depicting how ECT provides the feed back or the speed of adjustment. It gives an insight how short run dynamics converge towards the long run equilibrium in the model.

\section{Model 1: Short run Analysis of Budget Deficit}

Table 4.6: Error Correction Representation for ARDL Model 1

\begin{tabular}{lcccc}
\hline Variable & Coefficient & Std. Error & t-Statistic & Prob. \\
\hline D(LTOT) & 0.230932 & 0.195083 & 1.183761 & 0.2458 \\
D(LREM) & -0.493095 & 0.117425 & -4.199248 & 0.0002 \\
D(LREM(-1)) & -0.291801 & 0.122621 & -2.379700 & 0.0239 \\
D(LREM(-2)) & -0.394604 & 0.111777 & -3.530283 & 0.0014 \\
D(LFDI) & 0.159574 & 0.051968 & 3.070652 & 0.0045 \\
D(LFDI(-1)) & 0.044220 & 0.046913 & 0.942601 & 0.3534 \\
D(LRGDP) & -2.057254 & 1.367484 & -4.429488 & 0.0001 \\
D(LRGDP(-1)) & -1.545041 & 1.724489 & -3.215469 & 0.0031 \\
DUM08 & 0.399027 & 0.155991 & 2.558010 & 0.0158 \\
ECM_BD(-1) & 0.535414 & 0.091869 & 5.828050 & 0.0000 \\
R-squared & 0.666810 & Mean dependent var & -0.008699 & \\
Adjusted R-squared & 0.566853 & S.D. dependent var & 0.224940 & \\
S.E. of regression & 0.148042 & AIC & -0.770328 & \\
Sumsquared resid & 0.657490 & SIC & -0.348108 & \\
Log likelihood & 25.40655 & HIC & -0.617666 & \\
Durbin-Watson stat & 2.157349 & & & \\
\hline
\end{tabular}

Table 4.7: Results of Diagnostic Tests of Model 1

\begin{tabular}{lcc}
\hline Diagnostic Test & F-Statistics & P-value \\
\hline Serial Correlation (LM Test) & 0.32 & 0.72 \\
Heteroskedasticity (ARCH Test) & 1.37 & 0.24 \\
Normality Test (Jarque-Bera) & 3.37 & 0.19 \\
Model Specification (RAMSEY RESET) & 1.4 & 0.15 \\
\hline
\end{tabular}

The estimated error correction model is stable as indicated by the CUSUM test. The CUSUM test is shown in figure 4.1. The recursive estimate shows that the actual path of error correction model lies within the five percent critical band, appropriately qualifying CUSUM test. Various 


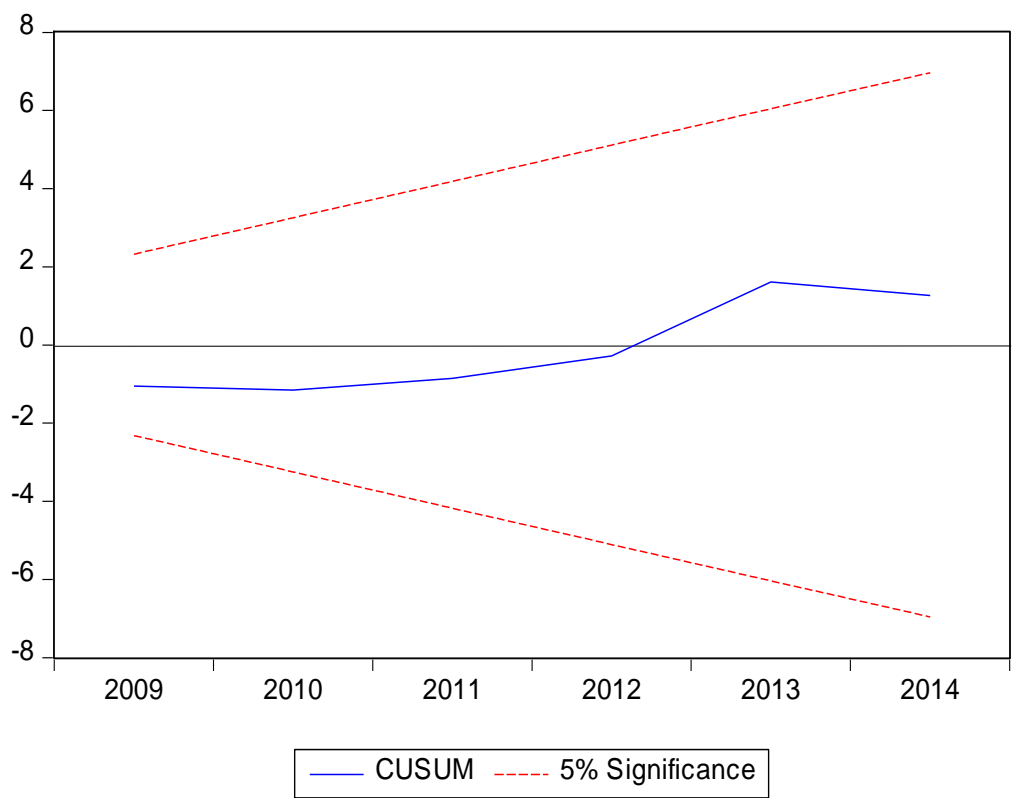

Figure 2:

disturbances in last few years have caused disturbances in the path but now the model 1 seems to catch up with the stability path smoothly as depicted in figure 4.1 .

\section{Model 2: Short run Analysis of Inflation}

\section{Model 3: Short run Analysis of Gross Domestic Product}

\section{Conclusion and Policy Recommendations}

This study is primarily aimed to explore the empirical evidences regarding the impact of various components of globalization on the economy of Pakistan through the performance of its selected macro variables (Budget Deficit, Inflation and Economic Growth). The proxy used for trade openness was shown by term of trade. Foreign Direct Investment was used as proxy for financial liberalization as percentage of GDP , taken as percentage of GDP. Remittances as percentage of GDP was used as proxy to capture the impact of labor mobility. The ARDL Methodology was used to analyze short run and long run dynamics among variables of three models.

For model 1,The long run estimates show that term of trade appeared to be negatively significant with budget deficit. Increasing trade openness provides more reforms that not only facilitates trade volumes but also enhances domestic competitions, which reduces budgetary imbalances. Remittances show positively significant long run relationship with budget deficit that gives insight into unproductive utilization of the remittances mostly for non-tradable goods or real estate sector along with increasing reliance on imports that tends to increase budget deficits. FDI seems to be positively and insignificantly related to budget deficit. FDI also need to have sound structural and industrial base to harness maximum gains from them. Real GDP is found to have negatively significant relationship with budget deficit. Increasing budget deficits are 
Table 4.8: Error Correction Representation for ARDL Model 2

\begin{tabular}{lcccc}
\hline Variable & Coefficient & Std. Error & t-Statistic & Prob. \\
\hline D(LTOT) & 0.149800 & 0.047389 & 3.161056 & 0.0033 \\
D(LFDI) & 0.018444 & 0.007099 & 2.598202 & 0.0138 \\
D(LFDI(-1)) & -0.027455 & 0.006984 & -3.931330 & 0.0004 \\
D(LREM) & 0.017252 & 0.015956 & 0.454511 & 0.6523 \\
D(LRGDP) & -2.576809 & 2.112987 & 0.035382 & 0.9720 \\
DUM08 & 0.086474 & 0.023207 & 3.726145 & 0.0007 \\
ECM_INF(-1) & -0.178729 & 0.042244 & -4.230884 & 0.0002 \\
R-squared & 0.659004 & Mean dependent var & -0.003369 & \\
Adjusted R-squared & 0.598828 & S.D. dependent var & 0.035234 & \\
S.E. of regression & 0.022317 & AIC & -4.612711 & \\
Sum squared resid & 0.016933 & SIC & -4.320150 & \\
Log likelihood & 101.5606 & HIC & -4.506177 & \\
Durbin-Watson stat & 2.226986 & & & \\
\hline
\end{tabular}

Table 4.9: Results for Diagnostic Tests for Model 2

\begin{tabular}{lcc}
\hline Diagnostic Test & F-Statistics & P-Value \\
\hline Serial Correlation (LM Test) & 2.58 & 0.12 \\
Heteroskedasticity (ARCH Test) & 0.21 & 0.64 \\
Normality Test (Jarque-Bera) & 2.26 & 0.29 \\
Model Specification (RAMSEY RESET) & 0.97 & 0.34 \\
\hline
\end{tabular}

associated with increasing default risks of governments along with inflationary risks that are detrimental to investment climate.

The short run trend results of model 1 showed positively insignificant relationship with budget deficit in the short run. Remittances are found to be negative and significant in the short run time period as they tend to increase consumption and investment prospects in economy thereby improving budget deficit. FDI has positively significant relationship with budget deficit in the short run as it generates more revenues for governments. The real GDP show negatively significant impact on budget deficit in the short run. The DUM08 used for financial crisis has positive and significant short run impact on budget deficit.

The long run estimates of model 2 for inflation concludes that term of trade significantly and positively contributes to inflationary pressures. The various economic ills like climate change, terrorism, energy crisis, political challenges have increased the costs of production that have sig- 


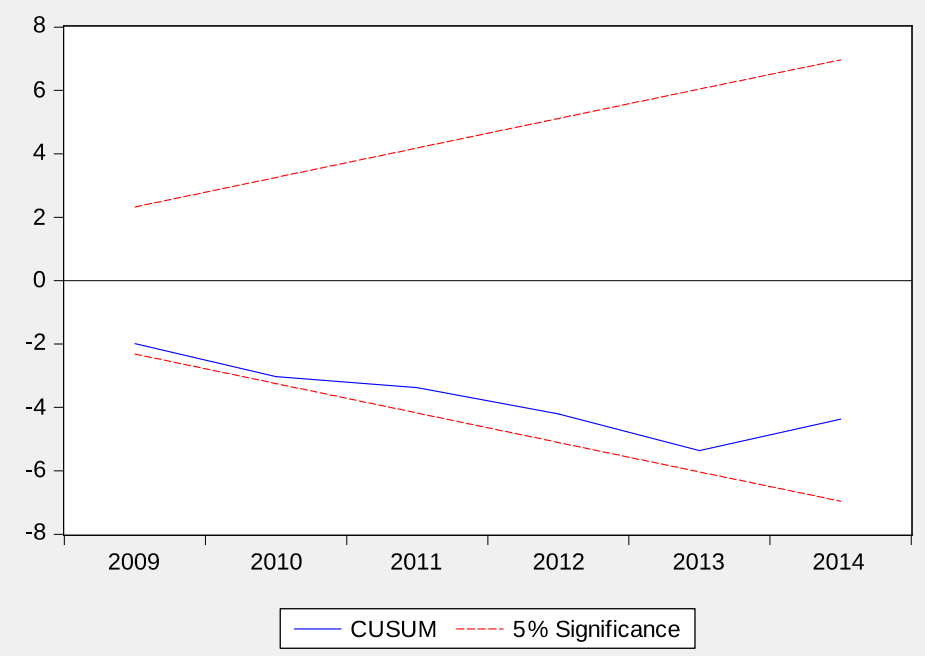

Figure 3:

Table 4.10: Error Correction Representation for ARDL Model 3

\begin{tabular}{lcccc}
\hline Variables & Coefficients & Std. Error & t- Statistic & Prob. \\
\hline D(LTOT) & 1.124067 & 0.032280 & 1.854583 & 0.0021 \\
D(LREM) & 0.776242 & 0.027981 & 2.936844 & 0.0553 \\
D(LFDI(-1)) & 0.462530 & 0.058301 & 0.953470 & 0.0588 \\
DUM08 & -0.027433 & 0.076531 & 0.976369 & 0.9560 \\
ECM_LRGDP(-1) & 1.051306 & 0.087676 & 1.110300 & 0.0000 \\
R-squared & 0.852907 & Mean dependent var & 0.099950 & \\
Adjusted R-squared & 0.387594 & S.D. dependent var & 0.018584 & \\
S.E. of regression & 0.064376 & AIC & 0.577668 & \\
Sum squared resid & 0.754327 & SIC & 0.319818 & \\
Log likelihood & 6.182876 & HIC & 0.078870 & \\
Durbin-Watson stat & 1.9878732 & & & \\
\hline
\end{tabular}

nificantly contributed to inflation. The FDI also appears to have positively significant relationship with inflation in the long run. Remittances also turn out to be significantly and positively linked to inflation in the long run for Dutch disease effect. The increasing imports, unproductive use of remittances in non-tradable sector etc. fail to generate much economic gains from 
Table 4.11: Results for Diagnostic Tests for Model 3

\begin{tabular}{lcc}
\hline Diagnostic Test & F-Statistics & P-Value \\
\hline Serial Correlation (LM Test) & 1.34 & 0.27 \\
Heteroskedasticity (ARCH Test) & 3.99 & 0.52 \\
Normality Test (Jarque-Bera) & 1.58 & 0.45 \\
Model Specification (RAMSEY RESET) & 0.62 & 0.53 \\
\hline
\end{tabular}

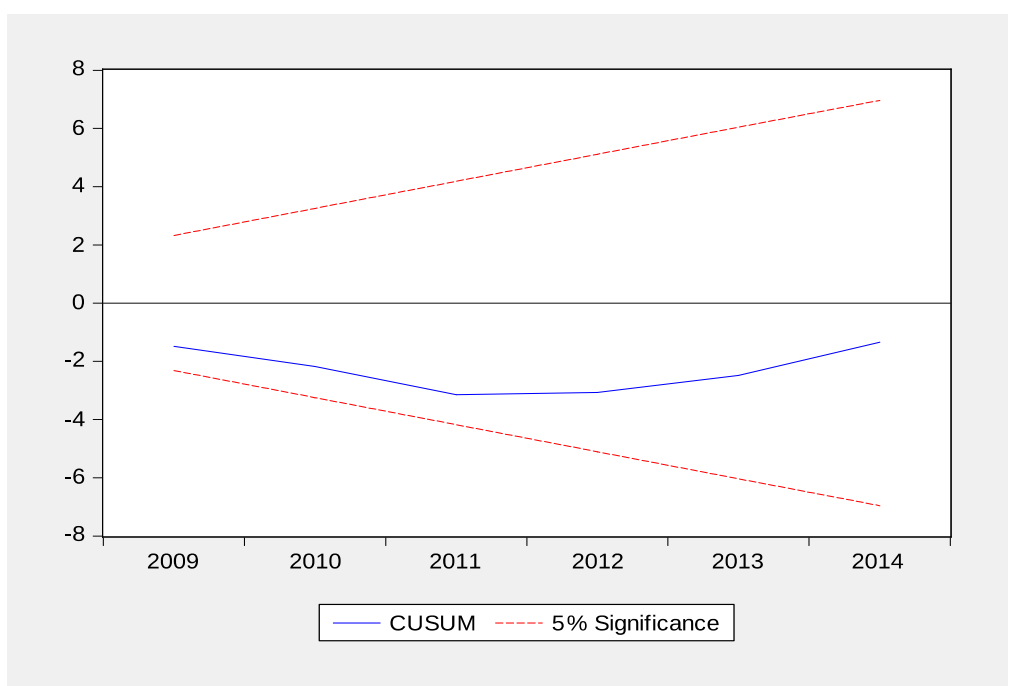

Figure 4: Research Framework

remittances. Remittances can pave way for demand pull inflation, increasing cost of business, reducing saving and investments hampering growth. Real growth shows negatively significant long run relationship with inflation which discourages investors to invest for increasing uncertainties related to economy that adversely affect all sections of society.

The short run analysis for model 2 shows positive and significant relationship between TOT and short run inflation trend. The increasing trade openness also makes economies more vulnerable to economic shocks and can expose such economies to increasing inflationary rates. FDI shows positively significant relationship with current inflation in empirical analysis. The first lag of FDI has negatively considerably significant impact on inflation in the short run. The FDI increases domestic competition facilitates revenue, employment, technology transfers that tend to reduce inflation. Remittances show positively insignificant short run relationship with inflation due to unproductive utilization of remittances. Real growth is negatively linked to inflation with insignificant impact in the short run. Dummy variable representing financial crisis 2008 implications show positively significant link with inflation in the short run.

The long run estimates of model 3 for real gross domestic product shows positively significant long run relationship between TOT and GDP. The trade openness paves way for compe- 
tition, access to cheap raw material that increases output and growth in the long run. Remittances are significant and positively related to real growth. They accelerate economic activity by increasing investment, consumption, generating more employment etc. that enhance growth. FDI is positively and significantly related to real growth by generating revenue, employment, human capital development, technology transfers etc. The dummy variable used for post 9/11 aid coming to Pakistan shows positively insignificant relationship with real growth.

The short run results for model 3 show that term of trade is positively and significantly linked to short run real GDP. Increasing trade openness provides access to cheap raw resources and diversified global markets that improve real growth in economies. Remittances also show significant and positive short run relationship with growth. Remittances promote financial development along with increasing economic activities that improve real growth. FDI in lag 1 is found to be significantly related to real growth in short run with positive impact. FDI through revenue generation, employment creation and technology transfers accelerate real growth. The dummy for financial crisis appear to be negatively insignificant with real growth in the short run.

\subsection{Policy Recommendations}

In the light of our empirical findings government needs to take various steps to initiate various structural and institutional reforms to harness maximum gains from FDI and attract more FDI. Budget deficits are not a problem as long resources are utilized for productive use. The governments need to cut down their lavish and unnecessary expenditures diverting them to productive expenditures like development expenditures. It will facilitate economic activity and improve the macroeconomic performance levels also. Government should also try to improve trade policies, giving special attention to export sector that is need of the hour to meet the global needs. It can improve export to import ratio thereby improving the performance of trade sector and reducing the economic burden of budget deficit. It is essentially required to improve our exports making them meet the global requirements to improve our current account that can also improve deficits. The deficits can also be greatly reduced by effective accountability of deficit utilization by the governments and making the productive use of the revenues. The meaningful and effective reforms in financial sector can also improve our deficit position. The government must pay special attention to control the illegal means like corruption, swindle, and nepotism to encourage and attract global investors towards healthy investment environment. Special privileges should be given to industrial sectors dealing in tradable goods to improve their production and make export sector more competitive. In addition special arrangements should be made to utilize remittances to more productive uses that can generate fruitful gains for economy. It is now essential to realize that world is more interconnected at present and we must be ready to face the global challenges along with enthusiasm to harness maximum possible gains of globalization.

\section{References}

Afzal, M. (2006). Causality between exports, world income and economic growth in pakistan. International Economic Journal, 20(1):63-77.

Agha, A. I., Khan, M. S., et al. (2006). An empiri- cal analysis of fiscal imbalances and inflation in pakistan. SBP research Bulletin, 2(2):343-362.

Aghion, P., Marinescu, I., Caballero, R. J., and Kashyap, A. K. (2007). Cyclical budgetary policy and economic growth: What do we learn from oecd panel data? [with comments and dis- 
cussion]. NBER Macroeconomics annual, 22:251297.

Agrawal, G. and Khan, M. A. (2011). Impact of fdi on gdp: A comparative study of china and india. International Journal of Business and Management, 6(10):71.

Alesina, A. and Perotti, R. (1995). The political economy of budget deficits. Staff Papers, 42(1):131.

Arezki, R. and Brückner, M. (2012). Rainfall, financial development, and remittances: Evidence from sub-saharan africa. Journal of International Economics, 87(2):377-385.

Asghar, N. and Hussain, Z. (2014). Financial development, trade openness and economic growth in developing countries: Recent evidence from panel data. Pakistan Economic and Social Review, pages 99-126.

Badinger, H. (2009). Globalization, the outputinflation tradeoff and inflation. European Economic Review, 53(8):888-907.

BAYRAK, M. and Ömer, E. (2012). Effects of budget deficit on current account balance: Analysis of twin deficits hypothesis in case of turkey. Ekonomik Yaklasim, 23(82):23-49.

Borio, C. E. and Filardo, A. J. (2007). Globalisation and inflation: New cross-country evidence on the global determinants of domestic inflation.

Collier, P. and Gunning, J. W. (1999). Trade shocks in developing countries. volume 1: Africa.

Combes, J.-L. and Saadi-Sedik, T. (2006). How does trade openness influence budget deficits in developing countries? The Journal of Development Studies, 42(8):1401-1416.

Friedman, T. L. (2005). The world is flat: A brief history of the twenty-first century. Macmillan.

Giuliano, P. and Ruiz-Arranz, M. (2009). Remittances, financial development, and growth. Journal of Development Economics, 90(1):144-152.

Guerrieri, L., Gust, C., and López-Salido, J. D. (2010). International competition and inflation: a new keynesian perspective. American Economic Journal: Macroeconomics, 2(4):247-80.
Javid, M., Arif, U., and Qayyum, A. (2012). Impact of remittances on economic growth and poverty. Academic Research International, 2(1):433.

Ju, J. and Wei, S.-J. (2010). Domestic institutions and the bypass effect of financial globalization. American Economic Journal: Economic Policy, 2(4):173-204.

Kim, E. H. and Singal, V. (2000). The fear of globalizing capital markets. Emerging Markets Review, 1(3):183-198.

Kose, M. A., Prasad, E. S., and Terrones, M. E. (2006). How do trade and financial integration affect the relationship between growth and volatility? Journal of international Economics, 69(1):176-202.

Lotfalipour, M. R., Montazeri, S., and Sedighi, S. (2013). Trade openness and inflation. evidence from mena region countries. Petroleum-Gas University of Ploiesti Bulletin, Technical Series, 65(2).

Makhlouf, F. and Mughal, M. (2011). Remittances, dutch disease, and competitiveness-a bayesian analysis.

Malit Jr, F. and Naufal, G. (2016). Taxing remittances: Consequences for migrant labor populations in the gcc countries. Gulf Labor Markets and Migration-An Explanatory Note, (1):1-16.

Meyer, D. and Shera, A. (2015). Remittances' impact on the labor supply and on the deficit of current account. Number 97. BERG Working Paper Series.

Mishkin, F. S. (2006). The next great globalization: how disadvantaged nations can harness their financial systems to get rich. Princeton University Press.

Obstfeld, M. (2004). Globalization, macroeconomic performance, and the exchange rates of emerging economies. Technical report, National Bureau of Economic Research.

Ratha, D. et al. (2005). Workers remittances: an important and stable source of external development finance. Remittances: development impact and future prospects, pages 19-51.

Romer, D. (1993). Openness and inflation: theory and evidence. The quarterly journal of economics, 108(4):869-903. 
Sentance, A. (2007). The global economy and uk inflation. Bank of England Quarterly Bulletin.

Shaikh, F. and Shah, M. (2008). Impact of globalization on pakistans economy by using cge model. In International Conference on Applied Economics, pages $839-845$.

Singh, K. (2000). Taming global financial flows: challenges and alternatives in the era of financial globalization: a citizen's guide. Zed Books.
Stiglitz, J. E. (2000). Capital market liberalization, economic growth, and instability. World development, 28(6):1075-1086.

Taylor, J. B. (2006). Implications of globalization for monetary policy. In Prepared for the academic consultants meeting, Federal Reserve Board.

Zakaria, M. (2010). Openness and inflation: evidence from time series data. 